\begin{tabular}{|c|c|c|c|c|c|c|c|c|}
\hline \multirow[b]{2}{*}{ Yeast } & \multirow{2}{*}{$\begin{array}{c}\text { Ex- } \\
\text { posure } \\
\text { time } \\
\text { (hr.) }\end{array}$} & \multirow{2}{*}{$\begin{array}{c}\text { No. of } \\
\text { cells } \\
\text { count- } \\
\text { ed }\end{array}$} & \multirow{2}{*}{$\begin{array}{c}\text { Per- } \\
\text { cent- } \\
\text { age } \\
\text { vege- } \\
\text { tative } \\
\text { cells }\end{array}$} & \multicolumn{4}{|c|}{ Percentage asci with } & \multirow{2}{*}{$\begin{array}{l}\text { Total } \\
\text { asci } \\
\text { (per } \\
\text { cent) }\end{array}$} \\
\hline & & & & $\begin{array}{c}1 \\
\text { sp. }\end{array}$ & $\underset{\text { sp. }}{2}$ & $\begin{array}{c}3 \\
\text { sp. }\end{array}$ & $\begin{array}{c}4 \\
\text { sp. }\end{array}$ & \\
\hline$G_{: a}$ & $\begin{array}{r}0 \\
8 \\
16\end{array}$ & $\begin{array}{l}566 \\
605 \\
323\end{array}$ & $\begin{array}{l}98 \cdot 0 \\
96 \cdot 4 \\
54 \cdot 5\end{array}$ & $\begin{array}{l}0 \cdot 2 \\
0 \cdot 8 \\
9 \cdot 3\end{array}$ & $\begin{array}{r}0.9 \\
1.0 \\
13.0\end{array}$ & $\begin{array}{r}0.9 \\
1.5 \\
16.4\end{array}$ & $\begin{array}{l}0 \\
0 \cdot 3 \\
6 \cdot 8\end{array}$ & $\begin{array}{r}2 \cdot 0 \\
3.6 \\
45.5\end{array}$ \\
\hline$G_{5}$ & $\begin{array}{r}0 \\
8 \\
16\end{array}$ & $\begin{array}{l}489 \\
610 \\
615\end{array}$ & $\begin{array}{l}57 \cdot 1 \\
75 \cdot 9 \\
89 \cdot 5\end{array}$ & $\begin{array}{l}2 \cdot 0 \\
2 \cdot 1 \\
1 \cdot 3\end{array}$ & $\begin{array}{r}18 \cdot 6 \\
7 \cdot 0 \\
3 \cdot 1\end{array}$ & $\begin{array}{l}9 \cdot 6 \\
9 \cdot 7 \\
4 \cdot 3\end{array}$ & $\begin{array}{r}12 \cdot 7 \\
5 \cdot 3 \\
1 \cdot 8\end{array}$ & $\begin{array}{l}42 \cdot 9 \\
24 \cdot 1 \\
10 \cdot 5\end{array}$ \\
\hline$G_{27}$ & $\begin{array}{r}0 \\
8 \\
16\end{array}$ & $\begin{array}{l}601 \\
620 \\
633\end{array}$ & $\begin{array}{l}97 \cdot 2 \\
97 \cdot 7 \\
96 \cdot 6\end{array}$ & $\begin{array}{l}1 \cdot 5 \\
1 \cdot 0 \\
2 \cdot 3\end{array}$ & $\begin{array}{l}0.7 \\
1.1 \\
0.9\end{array}$ & $\begin{array}{l}0.5 \\
0.2 \\
0.2\end{array}$ & $\begin{array}{l}0 \cdot 1 \\
0 \\
0\end{array}$ & $\begin{array}{l}2 \cdot 8 \\
2 \cdot 3 \\
3 \cdot 4\end{array}$ \\
\hline
\end{tabular}

Three typical examples of the results are given in Table 1.

Sornetimes when the experiments were repeated several times the results were identical; although at other times the results were different. Perhaps there is a certain period of sensitivity to light that may have a conclusive influence; but this has not yet been investigated. No doubt there exists an influence of light in inducing sporulation in the yeast strain $G_{2 a}$. In other strains the sporulation is inhibited as shown in the case of strain $G_{5}$. The third type is indifferent towards light, as the latter neither stimulates nor inhibits sporulation $\left(G_{27}\right)$. This was, however, only found with badly sporulating yeasts. On the other hand, no abundantly sporulating bottom yeast is known.

When the water of the 5-day-old cultures on gypsum blocks was replaced by a 0.1 per cent glucose solution, the sporulation sometimes could be improved without altering the proportion of the results. In one experiment 0.5 per cent sodium acetate produced no improvement.

The experiments will be extended with more exposure times. Where there is a sensitivity towards light, a substance, presumably a pigment, is probably responsible. This is to be investigated. With regard to this substance, the effectiveness of different wavelengths will be also examined.

Some strains show an influence of light on the rate of fermentation. When the cultures of these yeasts are exposed to artificial light during $24 \mathrm{hr}$. the rate of fermentation is decreased. This inhibition may explain the irregular results which are sometimes obtained.

Nationaal Instituut voor Brouwgerst,

W. F. F. OPPENOORTH

Mout en Bier, Rotterdam. July 23.

\section{Autolytic 'Protoplast' Release in Bacterium coli}

We recently discovered accidentally that controlled autolysis of certain Gram-positive bacteria in concentrated sucrose solutions adjusted to a critical ionic strength at $p \mathrm{H} 6$ results in the release of the internal protoplasts from the mechanical protection of the cellwall ${ }^{1,2}$. These 'protoplasts' are stable in suspension media of osmotic pressure above 20 atm., but lyse in more dilute media. The observations of Alfred Fischer $^{3}$ and Garbowski ${ }^{4}$ on plasmoptysis of certain Gram-negative bacteria in media of low salinity suggested that autolytic release of stable protoplasts might also be possible in these organisms. We have therefore made a preliminary investigation of the

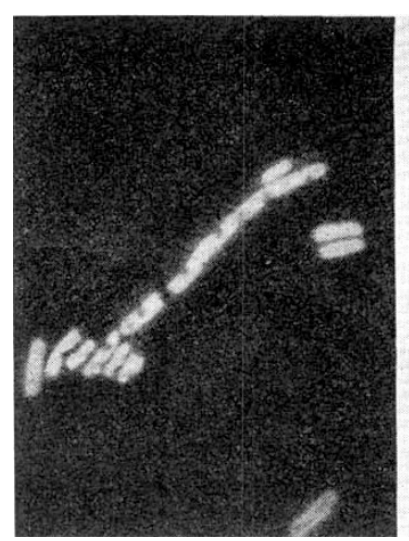

(a)

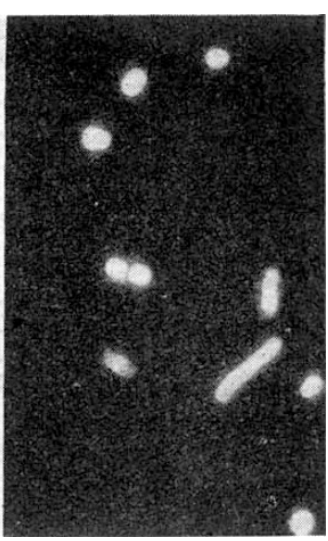

(b)
Fig. 1. Anoptral contrast micrographs of Bacterium coli (a) at commencement of incubation and $(b)$ after $12 \mathrm{hr}$. incubation in the controlled autolysis medium $(x 4,000)$

conditions required to release the protoplasts of Bacterium coli (American strain B).

The development of osmotic fragility-representing loss of tensile strength of the cell-wall-was measured by the degree of lysis of the organisms (depression of light scattering) when pipetted into a buffered medium of low osmotic pressure $(0.01 M$ phosphate buffer $p H$ 6.8) compared with equivalent samples pipetted into $M$ sodium chloride containing the same buffer. Rapid development of osmotic fragility without appreciable lysis of the 'protoplasts' occurs at $25^{\circ}$ in $0.3 \mathrm{M}$ sodium malonate in 0.5 molal $\mathrm{L}$-arabinose at neutral $p \mathrm{H}$. The rate of 'protoplast' release is greater the faster the growth of the organisms at harvesting; and, for exponential phase growth in an aerated 3 per cent tryptone, 1 per cent glucose, $0 \cdot 1$ per cent 'Marmite' medium at $25^{\circ}$, half the organisms become osmotically fragile in less than $60 \mathrm{~min}$.

Anoptral contrast microscopy (Messrs. Reichert, Austria) shows that the organisms are initially strongly plasmolysed in the autolysis medium (Fig. 1a). The chains of organisms become shorter as autolysis proceeds; but when complete osmotic fragility is achieved the organisms are still cylindrical. Transformation to spheres commences some hours later (Fig. 1b) and nears completion in about $12 \mathrm{hr}$. Similar results have been obtained with Aerobacter aerogenes although sphering is much more sluggish in this organism. It is possible that the plasma-membrane and/or protoplasm of these organisms normally possess enough mechanical rigidity to resist the tendency to assume a spherical shape even when the cell-wall has been lost or has ceased to possess mechanical rigidity.

We are indebted to Mr. R. A. Fox for photography, and to the Scottish Hospital Endowments Research Trust for grants in aid of this work.

\section{Peter Mrtohell}

Zoology Department,

University of Edinburgh. July 20.

Mitchell, P., and Moyle, J., Symp. Soc. Gen. Microbiol., 6, 150 (1956).

2 Mitchell, P., and Moyle, J., J. Gen. Microbiol. (in the press).

${ }^{3}$ Fischer, A., Ber. Deutsch. Bot. Gesellsch., 24, 55 (1906).

"Garbowski, L., Arch. Protistenk., 9, 53 (1907). 